\title{
Multinational Enterprises and Performance: Three Essays at the Interface between International Business and Strategic Management
}

\author{
Lars Matysiak \\ Ph.D. awarded by Justus Liebig University Giessen, Germany, December 2013
}

"What Determines the InTERnational Success and failure of firms?" has always been, still is and will most likely remain for some time the big question in international business research (Peng, 2004: 102). This question — which is not only of great interest to scholars, but also to practitioners - captures the overarching theme of my dissertation. In sum, my dissertation emphasizes the importance of firm-location interactions for multinational enterprise (MNE) performance. My dissertation consists of three papers, each of which contributes to getting closer to an answer to the big question by examining a unique issue related to MNEs and performance at the interface between international business and strategic management. Paper 1 emphasizes the need for research on MNE performance to re-focus on firm-specific advantages and country-specific advantages. Paper 2 points out that MNEs particularly benefit from exploiting firm-specific advantages in technology within their home triad region, whereas higher degrees of multinationality beyond the home triad region are generally associated with lower performance, regardless of firm-specific advantages. Finally, Paper 3 develops an integrative MNE dynamic capabilities research framework that explains how MNEs recombine resources and capabilities to augment existing or attain new non-location bound firm-specific advantages, location bound firm-specific advantages, and countryspecific advantages.

\section{Paper 1 - Antecedents of MNE Performance: Blinded by the Obvious in 35 Years of Literature}

Paper 1 is a systematic narrative literature review that examines the variety of antecedents of MNE performance. It makes two important findings. First, firm-level antecedents can be expected to have the strongest impact on MNE performance, while industry-level and country-level antecedents are less impactful. We deduce this from a summary of strategic management's market-based view (Porter, 1981) and resource-based view (Barney, 1991) as well as international business's internalization theory (Buckley \& Casson, 1976; Rugman, 1981), supplemented by an overview of analyses of variances. Second, empirical studies on antecedents of MNE performance seem to lack a coherent theoretical framework, hardly discuss their use of a diverse set of performance variables, and overwhelmingly focus on the degree of multinationality as an antecedent. We deduce this from a synthesis of 63 studies published in the three most important business and management journals for international business between 1976 and 2010.

Paper 1 contributes to the big question in international business research by emphasizing the need to re-focus on antecedents of MNE performance other than multinationality. In particular, we suggest that future research should more carefully consider firm-specific advantages and country-specific advantages as well as interactions between them. Accordingly, practitioners should base strategic decisions about operations in foreign countries on these very factors, which also means that multinationality is rather an intermediate variable. For policy makers, this implies that institutions may be designed to confer country-specific advantages, thereby attracting MNEs.

\section{Paper 2 - Antecedents of MNE Performance in the Home Region and Beyond}

Paper 2 of my dissertation is an empirical study that elucidates how the performance impact of firm-specific advantages varies with the degree of multinationality in an MNE's home triad region and with the degree of multinationality beyond an MNE's home triad region, i.e., in the rest of the world. We find, first of all, strong evidence for the regionalization perspective's (Rugman \& Verbeke, 2005) point that multinationality in the rest of the world is associated with higher costs and hence affects performance more negatively than home region multinationality. Second, we find that firm-specific advantages in technology primarily benefit MNEs with high degrees of home region multinationality. Finally, we find that international experience of MNEs' top management teams primarily benefits MNEs with high degrees of multinationality in the rest of the world. These findings are the results of robust fixed effects regression analyses of an original dataset comprising the largest listed German manufacturing MNEs (77 firms, 423 firm-year observations for the years 2004-2010).

The contribution of Paper 2 to the big question in international business research is to show that the performance impact of two types of firmspecific advantages that are usually considered to be non-location bound depends on their interaction with location at the regional level. Contrary to popular belief, MNEs do not seem to be able to exploit firmspecific advantages in technology anywhere in the world, but rather 
only in their home triad region. In the rest of the world, necessary investments in complementary assets may erode initial advantages. Furthermore, international experience of top management teams theoretically a microfoundation of a higher-order firm-specific advantage - does not improve the success of an MNE's operations within its home triad region, but somewhat alleviates the negative effects of operating beyond the home region in the rest of the world. This may be because top management teams primarily matter in so-called weak situations with ambiguity, complexity and high managerial discretion (Finkelstein et al., 2009), which are more likely in the rest of the world than within the home region. From the point of view of policy makers, Paper 2 provides arguments in favor of efforts to decrease administrative and economic distances, which together with cultural and geographic distances are key determinants of the costs of doing business abroad. The proposed Transatlantic Trade and Investment Partnership between the European Union and the United States may be an important step in this direction.

\section{Paper 3 - Towards a Dynamic Theory of the MNE: Resource-Capability Recombinations}

Paper 3 is a conceptual paper that integrates internalization theory, the resource-based view and the dynamic capabilities approach. It thereby advances the theory of the MNE to explicitly account for dynamic industry and country environments. We expound that an integration of the three abovementioned complementary theoretical perspectives is necessary in order to comprehensively explain the origin, creation and sustaining of MNEs' competitive advantages. Contemporary internalization theory distinguishes between non-location bound firm-specific advantages, location bound firm-specific advantages and countryspecific advantages (Verbeke, 2009), and it explains the optimal mode of cross-border transactions in which these three components of an MNE's competitive advantage are involved. However, its genesis as a static comparative institutional approach makes it inadequate to explain the origin, creation, and sustaining of these three components of competitive advantage. The resource-based view explains that competitive advantages as a whole originate from idiosyncratic resources and capabilities, but it is static and equilibrium oriented and thus inadequate to explain how firms create and sustain competitive advantages over time. The dynamic capabilities approach builds on the resource-based view to explain how firms create and sustain competitive advantages in dynamic environments via sensing, seizing and transforming (Teece, 2014), but it shares the resource-based view's shortcoming to only consider competitive advantages as a whole, not being able to distinguish between non-location bound and location bound firm-specific advantages and country specific advantages. Overcoming each perspective's shortcomings and combining their strengths, we develop an integrative MNE dynamic capabilities research framework that explains how MNEs recombine resources and capabilities to augment existing or attain new non-location bound firm-specific advantages, location bound firm-specific advantages and country- specific advantages via sensing, seizing and transforming in dynamic industry and country environments.

Paper 3 contributes to the big question in international business research by proposing that successful sensing, seizing and transforming in an international context requires MNEs to implement underlying processes and activities that are clearly aligned with the theoretical framework we develop. First, the processes and activities that undergird an MNE's sensing are more successful when they follow the extended resourcebased view logic we develop, which takes the international aspects of MNEs operations explicitly into account. Second, the processes and activities that undergird an MNE's seizing are more successful when they follow the logic of contemporary internalization theory. Third, the processes and activities that undergird an MNE's transforming are more successful when they follow the logic of international business's dominant theories about incentive structures and governance of transactions with foreign subsidiaries and external partners. In terms of international business and strategy education, Paper 3 implies that courses should not only teach the separate theories, but also provide guidance as to how processes and activities within firms can be better aligned to follow the theories' logics.

\section{References}

Barney, J. 1991. Firm resources and sustained competitive advantage. Journal of Management, 17(1): 99-120.

Buckley, P. J., \& Casson, M. 1976. The future of the multinational enterprise. London: Macmillan Press.

Finkelstein, S., Hambrick, D. C., \& Cannella, A. A. 2009. Strategic leadership: Theory and research on executives, top management teams, and boards. New York: Oxford University Press.

Matysiak, L., \& Bausch, A. 2012. Antecedents of MNE performance: Blinded by the obvious in 35 years of literature. Multinational Business Review, 20(2): 178-211.

Peng, M. W. 2004. Identifying the big question in international business research. Journal of International Business Studies, 35(2): 99-108.

Porter, M. E. 1981. The contributions of industrial organization to strategic management. Academy of Management Review, 6(4): 609-620.

Rugman, A. M. 1981. Inside the multinationals: The economics of internal markets. New York: Columbia University Press.

Rugman, A. M., \& Verbeke, A. 2005. Towards a theory of regional multinationals: A transaction cost economics approach. Management International Review, 45(Special Issue 1): 5-17.

Teece, D. J. 2014. A dynamic capabilities-based entrepreneurial theory of the multinational enterprise. Journal of International Business Studies, 45(1): 8-37. 
Verbeke, A. 2009. International business strategy: Rethinking the foundations of global corporate success. Cambridge: Cambridge University Press.

Lars Matysiak is an Assistant Professor in Strategic and International Management at the Justus Liebig University Giessen, Germany. His research focuses on successful strategies and structures of MNEs in different regions of the world and on MNEs' creation and exploitation of resources- and capabilities-based competitive advantages. He was awarded a Fellowship by the German National Academic Foundation and his work is published in the Multinational Business Review. 